\title{
Tectonic Rotation of the Kanto Mountains, Related with the Opening of the Japan Sea and Collision of the Tanzawa Block since Middle Miocene
}

\author{
Hiroshi Hyodo and Nobuaki NitTsumA \\ Institute of Geosciences, Shizuoka University, Shizuoka, Japan
}

(Received January 14, 1986)

\begin{abstract}
Paleomagnetic measurements were made on the early Miocene marine sediments in the Chichibu Basin of the Kanto Mountains, Central Japan. The mean paleomagnetic direction, $D=94^{\circ}, I=53^{\circ}\left(\alpha_{95}=8.3^{\circ}\right)$, indicates that the Kanto Mountains have not changed their latitude significantly, but have rotated clockwise through about $90^{\circ}$ since the middle Miocene. The rotation can be explained by the opening of the Japan Sea and the collision of the Tanzawa Block.
\end{abstract}

\section{Introduction}

The pre-Miocene geologic terrains of the Japanese Islands are characterized by zonal structure which extends with an east-west trend from Kyushu to Kanto district. This zonal structure makes a cusp northward about $100 \mathrm{~km}$ in Central Japan, as represented by the shape of the Median Tectonic Line (Fig. 1). NitTSUMA (1982) concluded that the descending of the Philippine Sea Plate initiated at 6-7 Ma in the Late Miocene, and that the cusp of the zonal structure was formed after that time. NiITSUMA and MATSUDA (1985) gave one explanation that the cusp was formed by collisions of the Tanzawa and the Izu Block on the basis of the exotic origin of the Tanzawa Block and the past plate motion.

In the Kanto Mountains located on the east wing of the cusp structure, paleomagnetic studies have been scarcely attempted heretofore. The Chichibu Tertiary System, exposed in the central part of the Kanto Mountains, consists of early Miocene marine sediments (Fig. 1). Defining the paleomagnetic direction in this area will give us a better understanding of the relationship between the rotation of Southwest Japan (OTOFUJI et al., 1985) and the formation of the cusp structure. In this paper, we describe the paleomagnetism on the early Miocene marine sediments of the Chichibu Basin and discuss a tectonic process to form the cusp of zonal structure in Central Japan.

\section{Geologic Setting}

The geologic map of the Chichibu Basin is shown in Fig. 2. The Basin extends about $15 \mathrm{~km}$ in an east-west direction and nearly $12 \mathrm{~km}$ in a north-south direction, and is filled with early Miocene marine sediments with a thickness of more than 6000 $\mathrm{m}$. The marine sedimentary basin is surrounded on all sides by pre-Tertiary rocks 


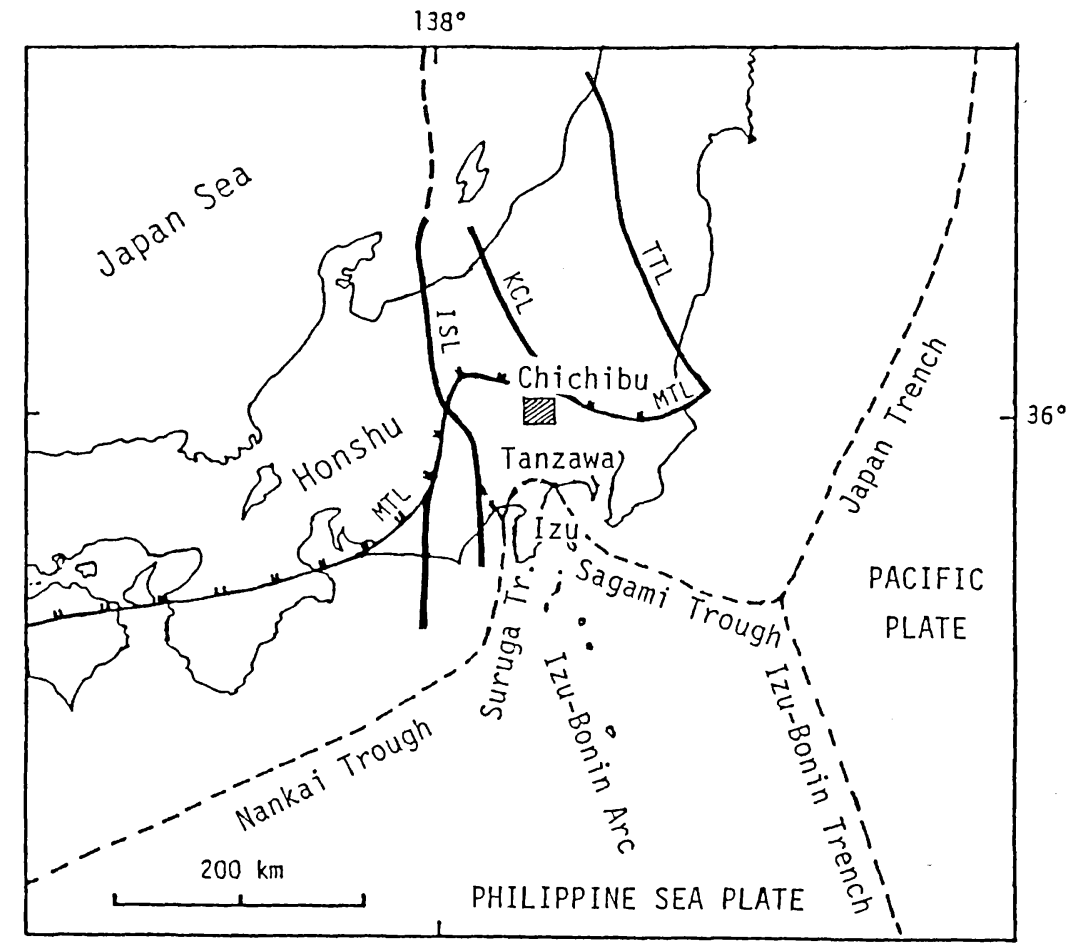

Fig. 1. Index map of the studied area (shaded rectangular). MTL: Median Tectonic Line. ISL: ItoigawaShizuoka Tectonic Line. KCL: Kashiwazaki-Choshi Tectonic Line. TTL: Tanakura Tectonic Line.

which are composed of the Chichibu System, the Sambagawa Metamorphics, and the Ryoseki-Monobegawa Series, with either faults or unconformities (ARAI, 1960). The marine strata are homoclinally dipping southeastward, while at the southeastern part of the basin the strata are irregularly folded.

We divided the early Miocene marine sediments into the following lithostratigraphic units in ascending order: Ushikubitoge Formation, Oganomachi Group, and Chichibumachi Group. The Ushikubitoge Formation consists of conglomerate and sandstone beds. The Oganomachi Group can be divided into three units in ascending order: mudstone dominant alternation (Miyato Formation), the alternation of equivalent amount of sandstone and mudstone (Yoshida Formation), and sandstone dominant alternation (Sakurai Formation). The Chichibumachi Group can be divided into five units in ascending order: massive muddy sandstone (Nagura Formation) with the intercalation of conglomerate (Shibahara Conglomerate Member), sandy mudstone (Saginosu Formation), conglomerate and sandstone (Tochiya Formation), and sandy mudstone with intercalation of conglomerate (Kamiterao Formation).

Microfossil assemblage from the Chichibu Tertiary System is assigned with Globigerinatella insueta/Globigerinoides trilobus and/or Globigerinita unicava zone of planktonic foraminifera (SAITO, 1963). SAITO and MAIYA (1973) correlated both of these zones with $\mathrm{N} 8$ of the Neogene foraminiferal zonation of BLOW (1969). 


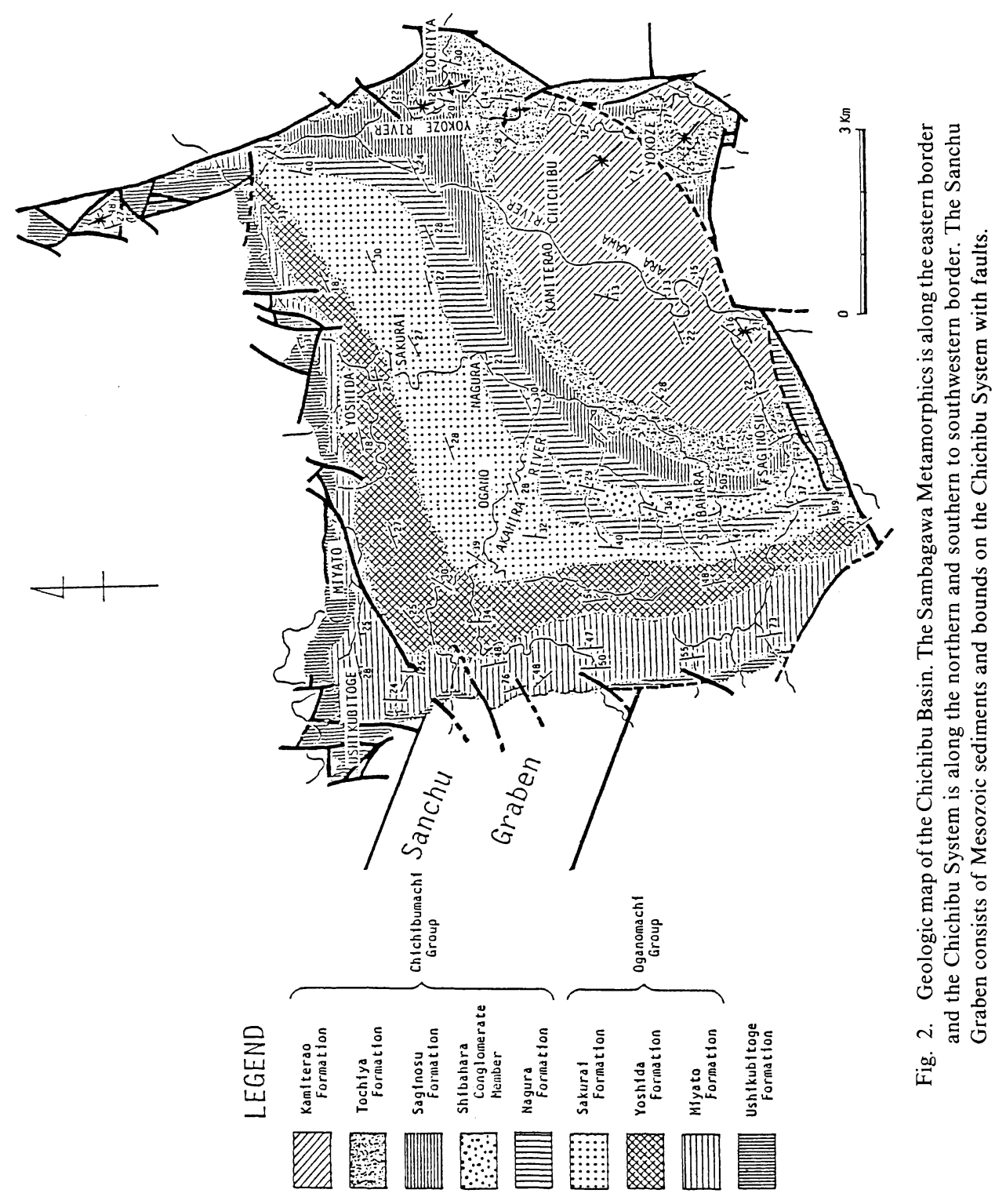




\section{Sampling and Measurement}

For a reconnaisance, paleomagnetic sampling was carried out at 133 sites on the early Miocene marine sediments in the Chichibu Basin (Fig. 3). We collected one oriented sample from each site. Sampling sites cover from the Ushikubitoge Formation to the Kamiterao Formation. Orientation was made with a magnetic compass. Samples were collected from tuff, tuffaceous sandstone, sandstone in alternation of sandstone and mudstone, muddy sandstone, sandy mudstone, and arkosic sandstone. Strike and dip of the strata were measured at each site to make tilt corrections of the paleomagnetic data.

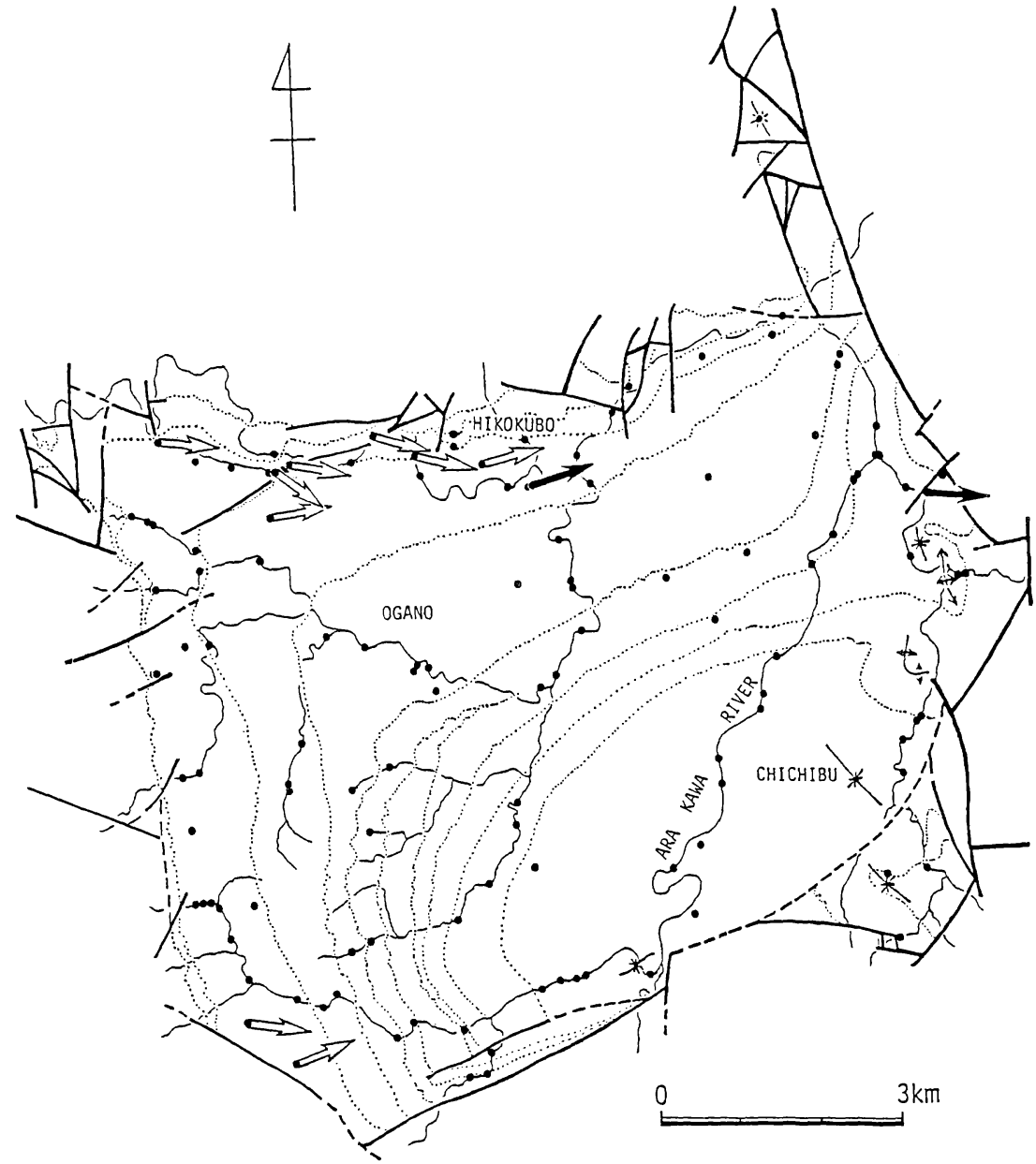

Fig. 3. Sampling localities (solid circle) for paleomagnetic study of the early Miocene marine sediments in the Chichibu Basin, Central Japan. Arrows indicates relative declinations of remanent magnetization. Solid arrow for the normal polarity, open arrow for reversed polarity. In the case of reversed polarity, open arrows show opposite direction. 
More than three cubic specimens were cut out from each hand sample. Remanent magnetizations were measured with a ring-core-type flux-gate spinner magnetometer. A current regulated three axial alternating field demagnetizer was used for magnetic cleaning (Nitssuma and Koyama, 1981; Koy AmA and Nitssuma, 1983).

One specimen from each hand sample was cleaned stepwise in alternating field (AF) up to 30 milli teslas (mT). Typical examples of magnetic behavior upon the AF-demagnetization are shown in Fig. 4. By the stepwise demagnetization, about half of the samples showed irregular changed and scattered directions within a hand sample (Fig. 4(a)). Such randomness of the magnetic direction is probably due to inhomogeneity of the initial magnetization process or to the weathering in these samples. In some sites, the remanent magnetizations remain parallel to the present geomagnetic field before tilt correction in spite of AF-demagnetization up to $35 \mathrm{mT}$ (Fig. 4(b)). In the other sites, a secondary magnetic component is easily erased with AF-demagnetization (Fig. 4(c)), or remanent magnetizations are stable under AFtreatment (Fig. 4(d)).

The following criteria were adopted to determine the reliability of the magnetic direction of each hand sample after AF-demagnetization;

i) Magnetic measurements are carried out twice around three orthogonal axis with normal and inversed spin directions, which yield 4 pairs of orthogonal magnetic vectors for each measurement. An angular dispersion can be calculated from the 4 pairs of vectors. A criterion is that the angular dispersion is less than $10^{\circ}$. The larger dispersion indicates an inhomogeneous magnetization within a specimen.

ii) The standard dispersion of remanent magnetic directions, which is given by $81 / \sqrt{k}$ (COLLINSON, 1983), is less than $22^{\circ}$ within a sample. The larger dispersion indicates an inhomogeneous magnetization within a sample.

iii) The $95 \%$ confidence circle within a sample does not include the present axial geocentric dipole field direction before a tilt correction. The sample which does not pass this criterion can be regarded to have remagnetized by the present magnetic field after the tilting of strata.

iv) The absolute value of the mean inclination ranges from $35^{\circ}$ to $70^{\circ}$ after a tilt correction. The sample which does not pass this criterion can be regarded to have recorded transient feature of the geomagnetism such as a polarity transition.

Sites not passing these four criteria were rejected. As the result, remanent magnetization of 12 hand samples were regarded as a reliable magnetic direction.

Intensities of natural remanent magnetization (NRM) in all samples range from $2 \times 10^{-7} \mathrm{kA} / \mathrm{m}$ to $6 \times 10^{-5} \mathrm{kA} / \mathrm{m}$, and intensities after the demagnetization range from $6 \times 10^{-8} \mathrm{kA} / \mathrm{m}$ to $2 \times 10^{-5} \mathrm{kA} / \mathrm{m}$ (Fig. 5). The most sites with an intensity less than $5 \times 10^{-7} \mathrm{kA} / \mathrm{m}$ were rejected with the criteria $\mathrm{i}$ and ii. The rejected sites with criterion iii have larger intensity of more than $5 \times 10^{-7} \mathrm{kA} / \mathrm{m}$. The rejected sites with criterion iv do not have any correlation with their intensities.

We collected more than two oriented samples from the same outcrops of the above-mentioned 12 hand samples to average out an error of sample orientation and a inhomogeneity between sample magnetization. Several cubic specimens were cut out from each sample and measured them after AF-demagnetization. Adopting the four criteria, one of those sites, however, does not pass the criterion ii.

In addition to AF-demagnetization, we tried thermal demagnetization to the samples of these 11 sites and some of the rejected sites by a microwave heating method 


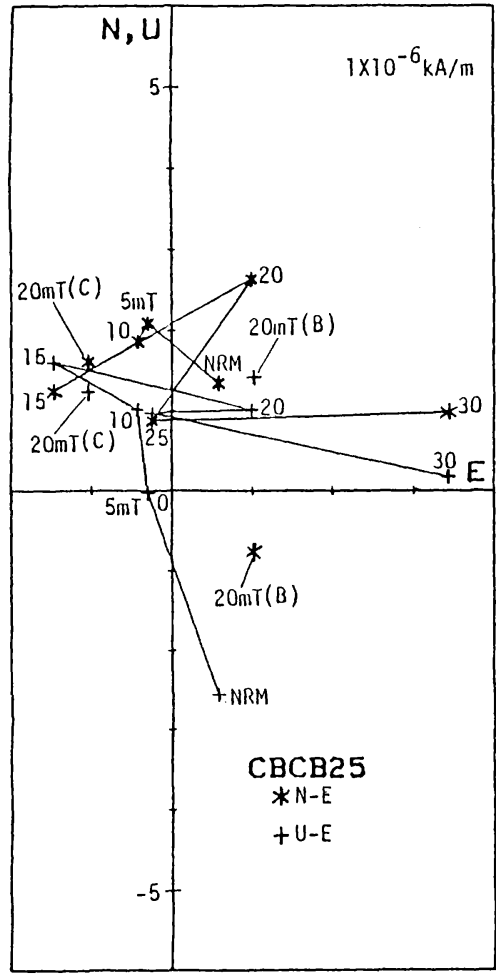

(a)

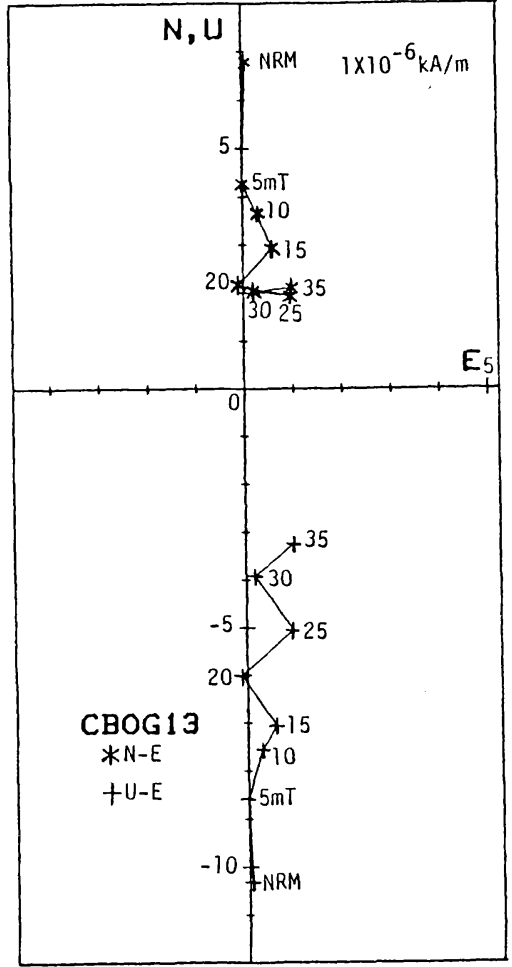

(b)

Fig. 4. Changes in the direction of remanent magnetization during the stepwise AF- and MWdemagnetization. Numbers in figure represent the intensities of AF-demagnetization (mT) and duration of MW-demagnetization (min). One division of scale is $1 \times 10^{-6} \mathrm{kA} / \mathrm{m}$ for $(\mathrm{a}, \mathrm{b}, \mathrm{c}, \mathrm{d}, \mathrm{f})$ and $1 \times 10^{-7} \mathrm{kA} / \mathrm{m}$ for (e). (a): The remanent magnetization changes irregularly by the stepwise AFdemagnetization. (B) and (C): the directions of other two specimens from the hand sample. (b): The remanent magnetization is parallel to the present geomagnetic field through all step of the AFdemagnetization before tilt correction. (c): The secondary soft component can be erased by AFdemagnetization. (d): The remanent magnetization are stable by AF-demagnetization with the original direction of normal polarity. (e): The remanent magnetization changes unsystematically under the stepwise MW-demagnetization. (f): The remanent magnetization of reliable site is stable under MW-demagnetization.

(microwave demagnetization: MW-demagnetization: HALE et al., 1978; TAMURA et al., 1984). The surface temperature of the sediment sample was observed to be more than $240^{\circ} \mathrm{C}$ under radiation up to 10 minutes.

Some of the samples rejected by the criterion iii, which are parallel to the present geomagnetic field after AF-demagnetization, change their direction of remanent magnetization by the stepwise MW-demagnetization up to 10 minutes. However the directions at each step did not show systematic trends as typically shown in Fig. 4(e). On the other hand, all of the samples of above 11 sites were found to be stable by MW-demagnetization up to $240^{\circ} \mathrm{C}$ (Fig. 4(f)). 


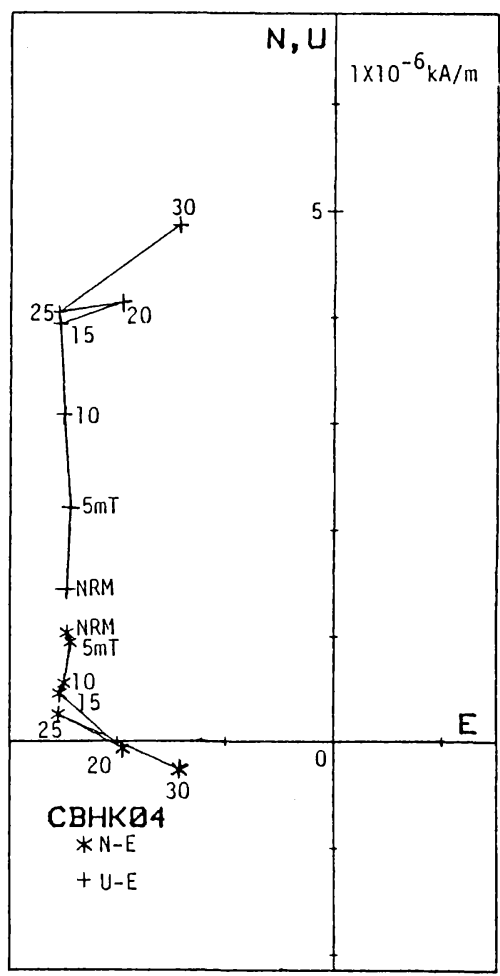

(c)

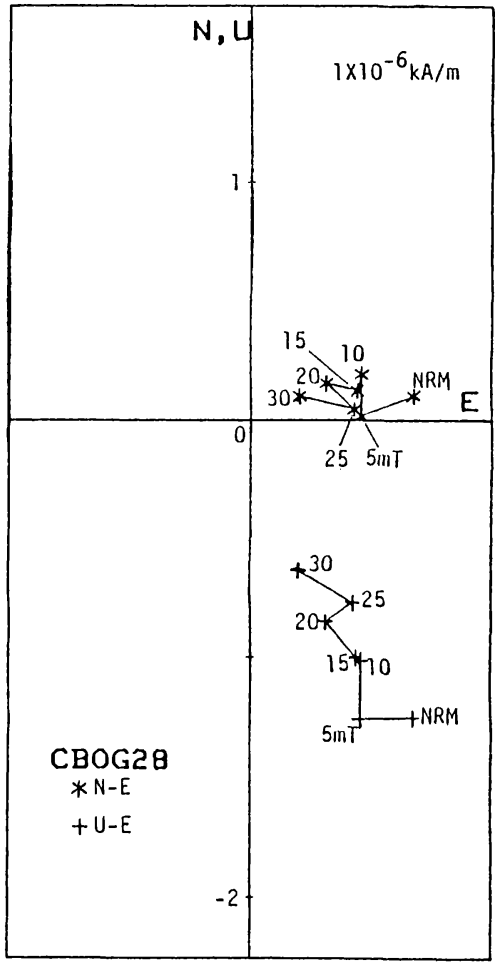

(d)

Fig. 4 (continued).

Consequently these 11 sites are regarded to show reliable paleomagnetic directions as shown in Fig. 6 and Table 1. The lithofacies of the selected sites are medium and coarse grained sandstone with fine parallel laminations, tuff, and tuffaceous sandstone.

\section{Discussion and Conclusion}

Site-mean direction of the reliable 11 sites is $D=93.7^{\circ}$ and $I=52.7^{\circ}$ with the radius of the $95 \%$ confidence circle $\left(\alpha_{95}\right)$ of $8.3^{\circ}$, after inversion of the reversed polarity directions to the normal polarity. The mean declination is deflected easterly from the north (Fig. 6). The mean inclination is not significantly different from that of the geocentric axial dipole field $\left(56^{\circ}\right)$. These 11 sites include both normal polarity (in upper two sites) and reversed polarity (in lower 9 sites), so that the mean paleomagnetic direction represents a sufficiently long period to average the geomagnetic secular variation. Sampling sites which yielded reliable directions are distributed in the northern part and in the southwestern part of the Chichibu Basin (Fig. 3). Concordant paleomagnetic directions indicate the easterly deflection of the mean paleomagnetic direction is not a result of local tectonic disturbance within the 


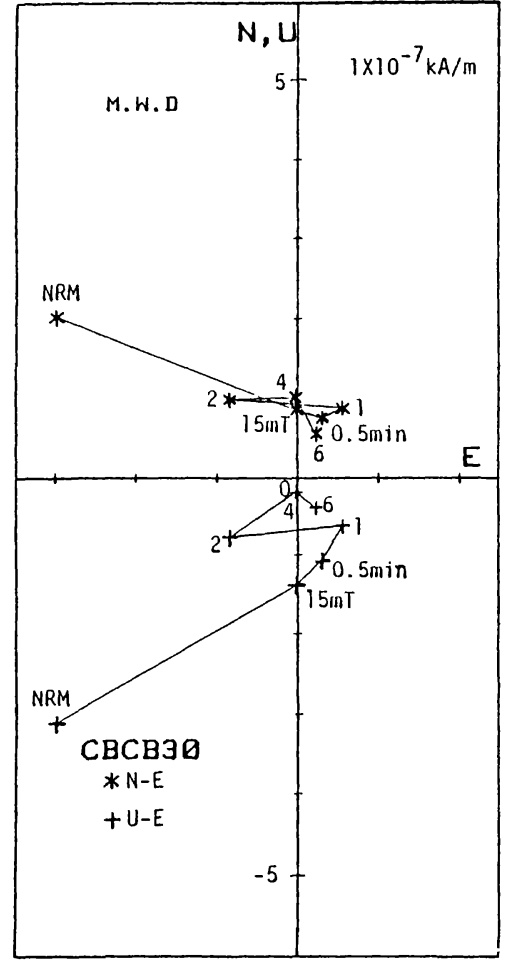

(e)

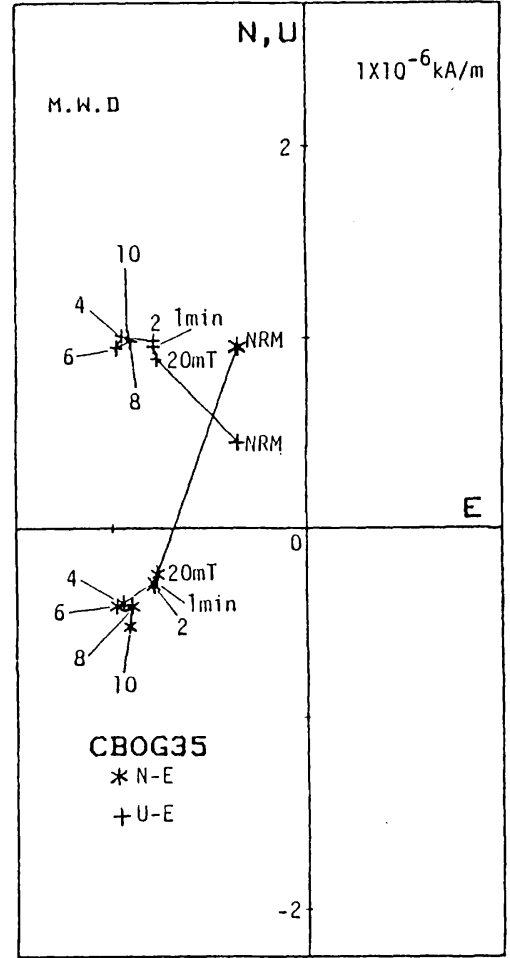

(f)

Fig. 4 (continued).

basin. These facts suggest that the paleomagnetic direction of the Chichibu Basin can be assumed to represent an average dipole field direction. The significant deflection of the paleomagnetic direction implies some tectonic rotation of the studied area.

The stratigraphic distribution of normal and reversed polarity sites is shown in Fig. 7. NIITSUMA and AKIBA (1985), and HsÜ et al. (1984) suggested that the N 9 / N 8 biostratigraphic boundary of Blow's Foraminiferal Zone lies around the ocean magnetic anomaly 5B. The Chichibu Tertiary System is correlated with Blow's Foraminiferal Zone N 8. The Orblina datum which corresponds to the N $9 / \mathrm{N} 8$ boundary has not been reported in this Tertiary System. Therefore the upper horizons with normal polarity can be correlated magnetostratigraphically with the ocean magnetic anomaly 5B. It can be concluded that the Kanto Mountains including the Chichibu Basin was rotated clockwise $94^{\circ}$ relative to the geomagnetic field after 15 Ma.

The direction of the zonal structure of the pre-Neogene rocks in the Kanto Mountains is represented by the general trend of the Sanchu Graben which is composed of Cretaceous sediments (Ryoseki-Monobegawa Series) and extend about $40 \mathrm{~km}$ to WNW-ESE with a width of $3 \mathrm{~km}$ parallel to the zonal structure (INOUE, 1974). The present direction of the zonal structure is $115^{\circ}$ clockwise from the north 


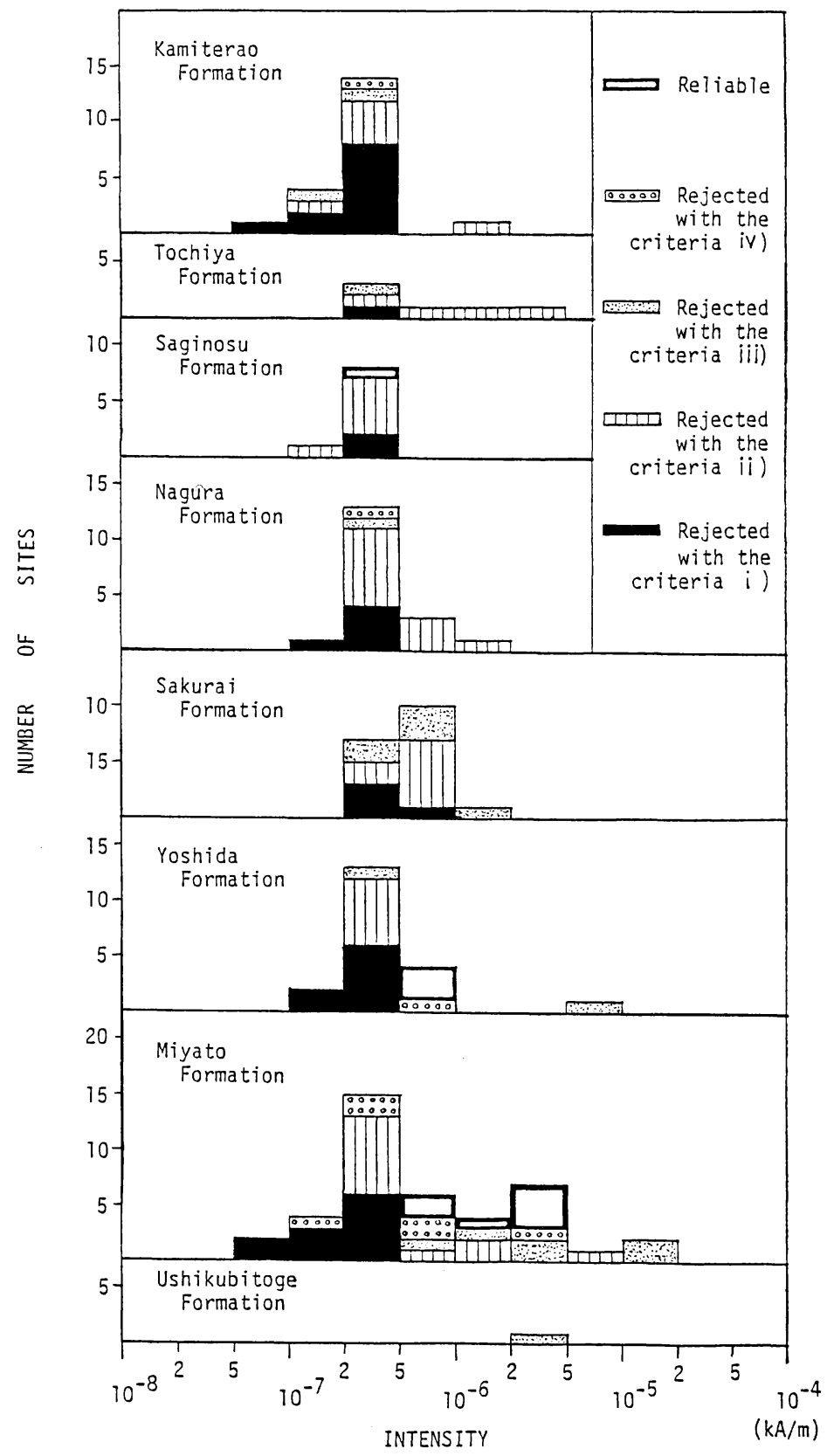

Fig. 5. Histograms of rejected site number versus remanent intensity in each Formation.

(Fig. 2). Before the rotation of the Kanto Mountains (15 Ma), the trend of the zonal structure can be calculated as $\mathrm{N} 21^{\circ} \mathrm{E}$ in this area on the basis of the present paleomagnetic result. It is reported that Southwest Japan rotated through $47^{\circ}$ after 15 


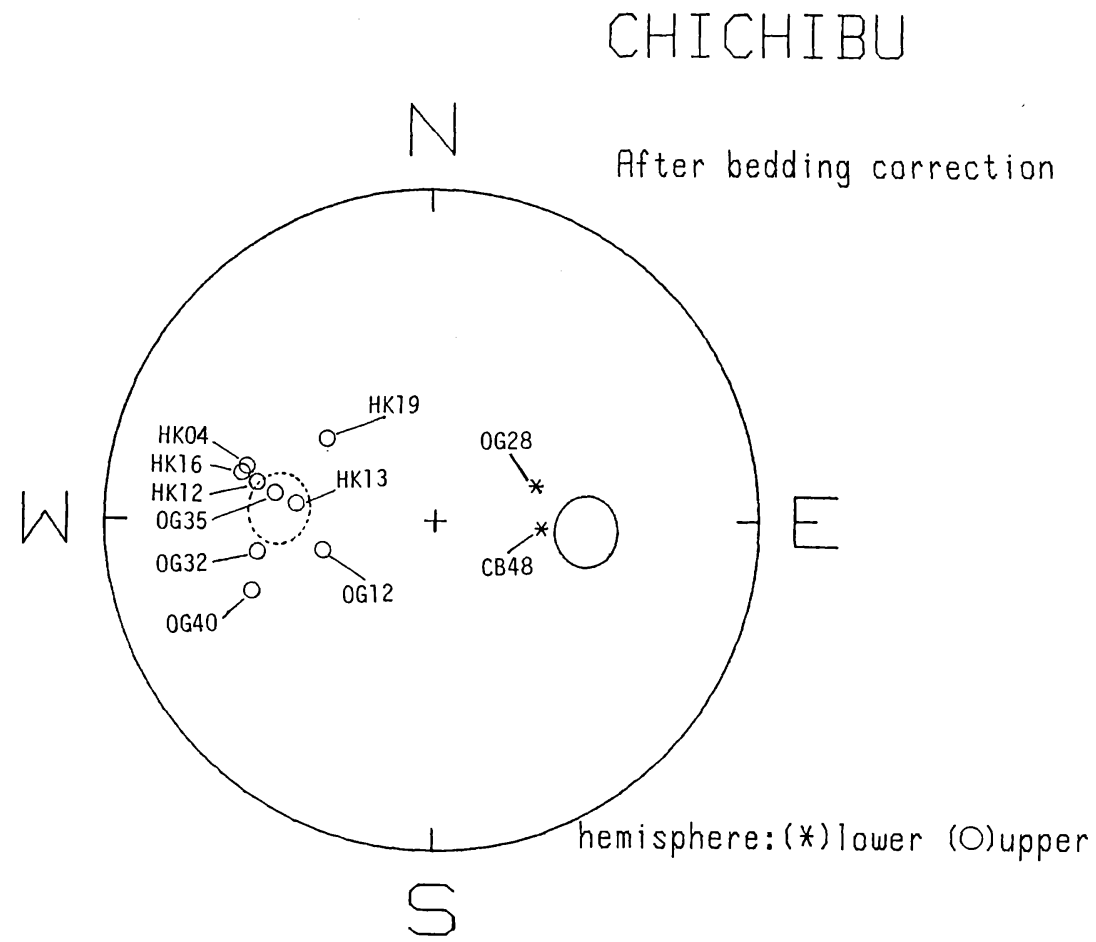

Fig. 6. Reliable directions of remanent magnetization of the early Miocene marine sediments in the Chichibu Basin, Central Japan. Circles represents 95\% confidence limit of mean direction; solid line on lower hemisphere and dotted line on upper hemisphere.

Table 1. Reliable remanent magnetizations of the early Miocene marine sediments in the Chichibu Basin, Central Japan.

\begin{tabular}{rrrrrrrrrrrrrr}
\hline Site & $\begin{array}{c}\text { Horizon } \\
(\mathrm{m})\end{array}$ & $\begin{array}{l}\text { AFD } \\
(\mathrm{mT})\end{array}$ & $D$ & $I$ & $\begin{array}{c}D \\
\text { (corrected) }\end{array}$ & & & & & \multicolumn{1}{c}{$\begin{array}{c}\text { Lat } \\
(\mathrm{N})\end{array}$} & $\begin{array}{c}\text { Long } \\
(\mathrm{E})\end{array}$ & Lith \\
\hline CB48 & 5550 & 3 & 10 & $68.2^{\circ}$ & $59.9^{\circ}$ & $93.7^{\circ}$ & $63.6^{\circ}$ & 56.8 & $16.5^{\circ}$ & $10.7^{\circ}$ & $22.9^{\circ}$ & $171.9^{\circ}$ & $\mathrm{S}$ \\
OG28 & 2708 & 5 & 20 & 29.8 & 51.8 & 70.4 & 63.6 & 424.2 & 3.7 & 3.9 & 37.5 & 164.3 & $\mathrm{~T}$ \\
OG12 & 2323 & 5 & 15 & 224.6 & -57.4 & 254.9 & -61.4 & 39.6 & 12.3 & 12.9 & 33.5 & 162.4 & $\mathrm{~S}$ \\
OG32 & 2299 & 5 & 25 & 235.9 & -57.5 & 260.3 & -44.6 & 24.3 & 15.9 & 16.5 & 22.5 & 147.9 & $\mathrm{~S}$ \\
OG40 & 1136 & 5 & 20 & 3.9 & -63.1 & 249.4 & -40.2 & 81.3 & 8.5 & 9.0 & 29.4 & 139.2 & TS \\
OG35 & 911 & 5 & 20 & 14.8 & -51.5 & 279.6 & -49.6 & 18.7 & 18.1 & 18.7 & 10.4 & 161.1 & TS \\
HK16 & 647 & 4 & 25 & 258.3 & -42.7 & 284.2 & -39.4 & 51.8 & 12.9 & 11.3 & 2.3 & 157.2 & TS \\
HK19 & 635 & 5 & 25 & 257.9 & -56.4 & 307.4 & -56.6 & 173.1 & 5.8 & 6.2 & 2.1 & 178.3 & TS \\
HK13 & 613 & 6 & 20 & 270.9 & -50.2 & 276.8 & -55.6 & 17.3 & 16.6 & 19.5 & 15.6 & 164.6 & TS \\
HK12 & 594 & 5 & 25 & 250.5 & -56.6 & 282.0 & -44.0 & 76.8 & 8.8 & 9.2 & 6.0 & 158.7 & S \\
HK04 & 536 & 5 & 15 & 268.0 & -33.0 & 286.2 & -40.5 & 16.0 & 19.7 & 20.3 & 1.3 & 158.9 & S \\
\hline
\end{tabular}

$N$ : number of specimen. AFD: field strength of alternating field demagnetization. $D, I$ : declination and inclination of remanent magnetization before tilt correction. $D, I$ (corrected): declination and inclination of remanent magnetization after tilt correction. $k$ : precision parameter. $\alpha_{95}$ : radius of the $95 \%$ confidence circle of the measured direction in the site. $\sigma$ : radius of angular standard dispersion of paleomagnetic directions which is given by $81 / \sqrt{k}$. Lat, Long: latitude and longitude of virtual geomagnetic pole position (north-seeking pole). Lith: lithology (S: sandstone. M: mudstone. T: tuff. TS: tuffaceous sandstone). 


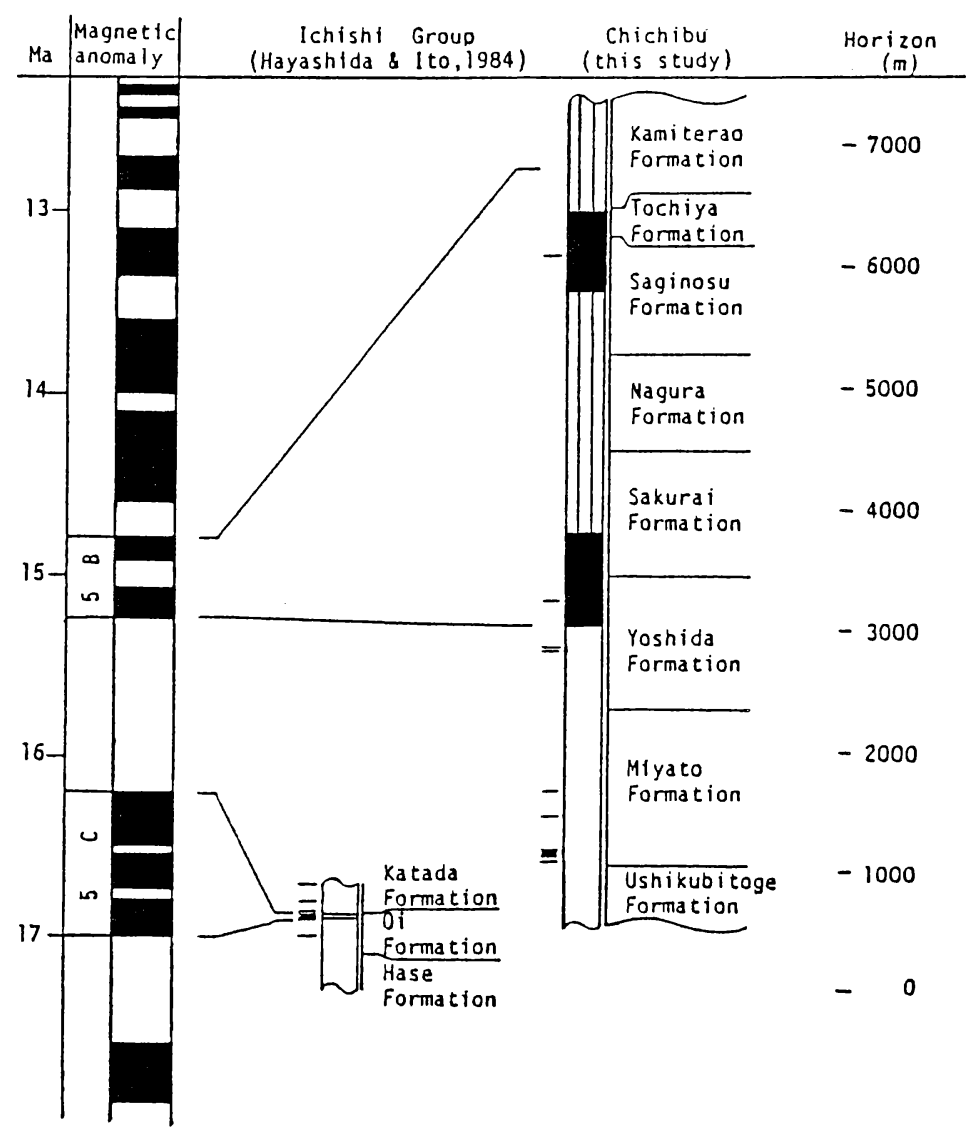

Fig. 7. Magnetostratigraphic correlation of the early Miocene marine sediments in the Chichibu Basin, Central Japan, with the ocean magnetic anomaly sequence and the early Miocene marine sediments in the Ichishi area, Southwest Japan (HAYAShidA and ITO, 1984). The longitudial lines in the magnetostratigraphic column of this study indicate the stratigraphic interval without reliable paleomagnetic sample.

Ma (ОтоFUJi et al., 1985) as shown in Fig. 8. The present direction of the zonal structure in Southwest Japan is $73^{\circ}$ clockwise from the north, that is to say, the trend was $\mathrm{N} 26^{\circ} \mathrm{E}$ before $15 \mathrm{Ma}$. This trend is consistent with the restored direction of the zonal structure in the Kanto Mountains (N $\left.21^{\circ} \mathrm{E}\right)$. This consistency suggests that the zonal structure in Central Japan has not bent and run straight from Southwest Japan to the Kanto Mountains before 15 Ma (Fig. 9).

It is possible to assume that the Kanto Mountains was rotated about $47^{\circ}$ as a part of the Southwest Japan at $15 \mathrm{Ma}$. Then we can further assume that the rest of the rotation, about $45^{\circ}$, occurred after $15 \mathrm{Ma}$. It can be interpreted that the latter rotation of the Kanto Mountains may be accommodated with the collision of the Tanzawa Block since $6 \mathrm{Ma}$. The initiation of the descent of the Philippine Sea Plate is estimated at 6-7 Ma of late Miocene, based on the plate motion (MINSTER and JORDAN, 1979), 


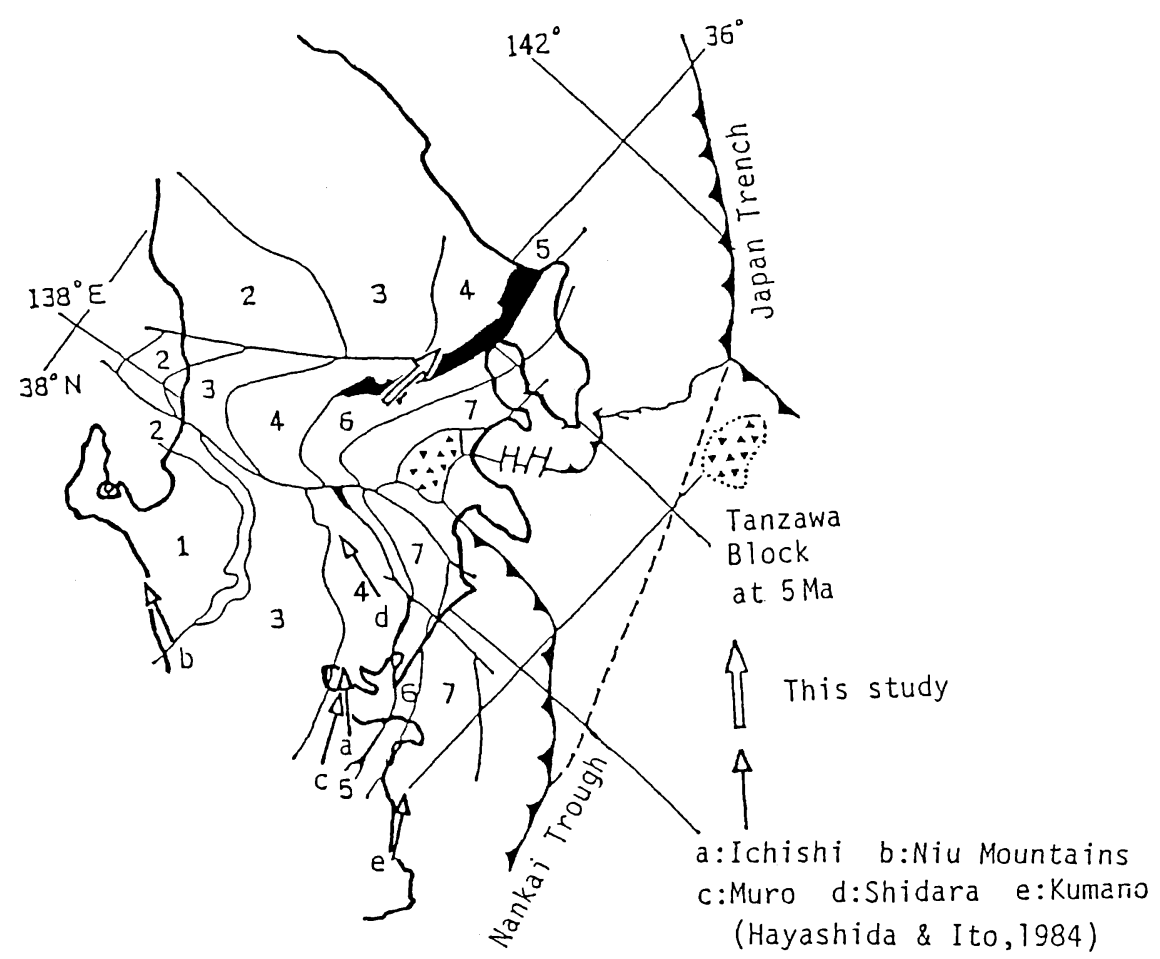

Fig. 8. The bent shape of pre-Miocene zonal structure and the paleomagnetic directions of the early Miocene marine sediments and volcanics from Southwest Japan (HAYASHIDA and ITO, 1984) and the Kanto Mountains. 1: Hida Belt. 2: Hida Marginal-Joetsu Belt. 3: Mino-Tanba-Ashio Belt. 4: Ryoke Belt. 5: Sambagawa Belt. 6: Chichibu and Sambosan Belts (black). 7: Shimanto Belt. Median Tectonic Line is defined as the boundary between Ryoke Belt (4) and Sambagawa Belt (5).

the sedimentary sequences, and Wadati-Benioff zone along the Ryukyu Trench and the Nankai Trough (NIITSUMA and AKIBA, 1985). Because the Tanzawa Block is composed of arc volcanic rocks of the Izu-Bonin Arc of the Philippine Sea Plate, it is suggested that the block could have been moved from the outside of the connected line between the Nankai Trough and the Japan Trench since 6 Ma by the present plate motion (Fig. 8). The cusp of the zonal structure is parallel to the Sagami, Suruga and Nankai Troughs which indicate the present northern boundary of the Philippine Sea Plate. It can be assumed, therefore, that the bend of the zonal structure and the plate boundary have been formed by the indentation of the Tanzawa Block of the Philippine Sea Plate to the straight zonal structure of Southwest Japan during the last $6 \mathrm{Ma}$.

The authors wish to thank I. Machida and O. Sakamoto of Saitama Museum of Natural History for their kind help during the field survey, suggestion and discussions. Y. Saito of National Science Museum, Tokyo, A. Taira of Ocean Research Institute, University of Tokyo, K. Ishizaki of Tohoku University, M. Torii of Kyoto University, Y. Otofuji of Kobe University and A. Hayashida of Doshisha University for their suggestions, discussions and information. 


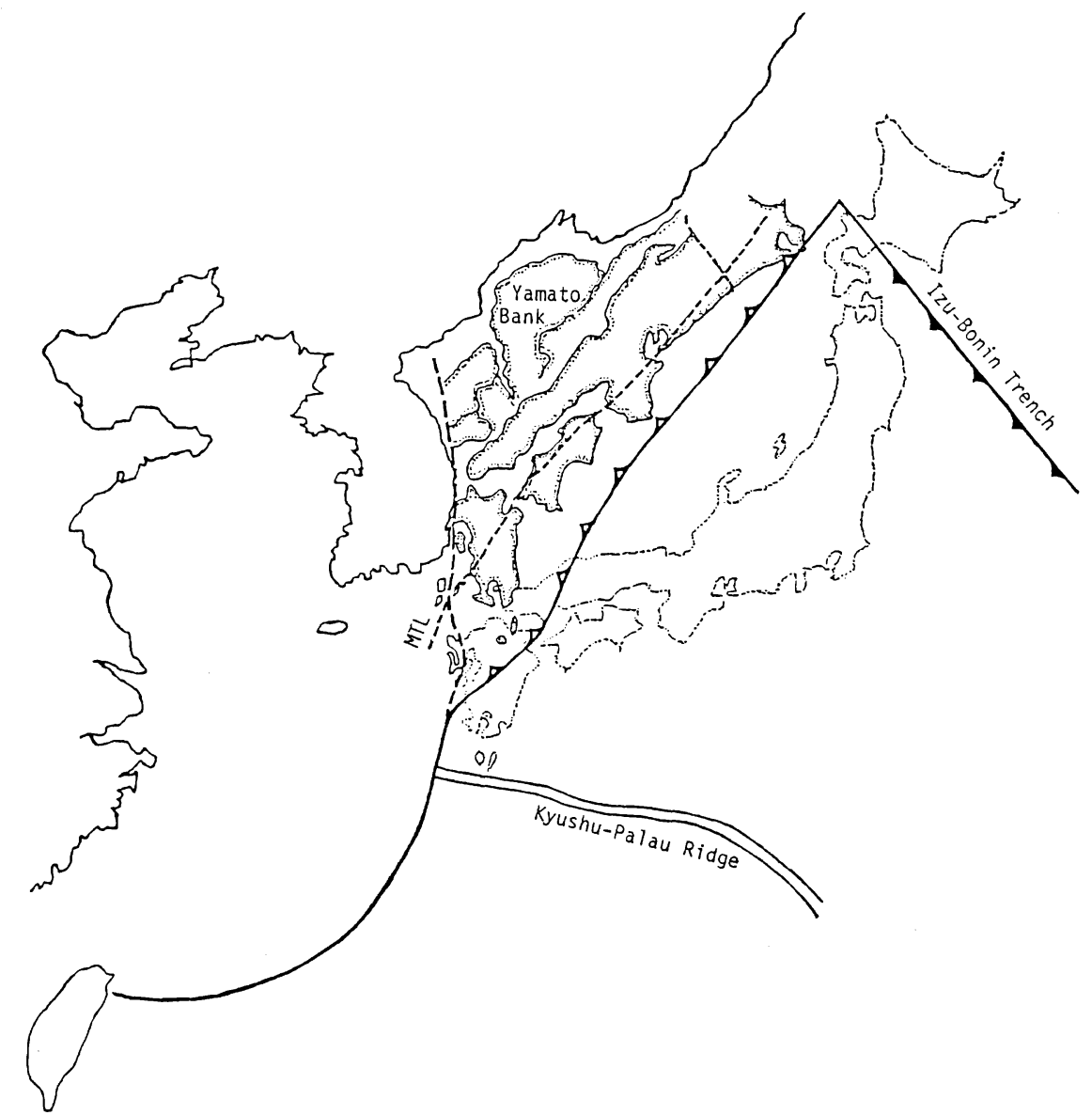

Fig. 9. Reconstruction of the Japanese Islands before opening of the Japan Sea and the indentation of the Tanzawa Block, based on the present paleomagnetic results. MTL: Median Tectonic Line.

\section{REFERENCES}

AraI, J., The Tertiary System of Chichibu Basin, Saitama Prefecture, Central Japan: Part I. Sedimentology, pp. 1-122, Jpn. Soc. Prompt. Sci., Tokyo, 1960.

Blow, W. H., Late Middle Eocene to Recent planktonic foraminiferal biostratigraphy, in Proc. 1st Int. Conf. Planktonic Microfossils, E. J. Brill, Leiden, Vol. 1, edited by P. Bronimann and H. H. Renz., pp. 199-421, 1969.

Collinson, D. W., Methods in Rock Magnetism and Paleomagnetism, Techniques and Instrumentation, pp. 360-398, Chapman and Hall, London, 1983.

Hale, C. J., M. Fuuler, and R. C. Bailey, On the application of microwave heating to lunner paleointensity determination, Proc. 9th Lunner and Planet. Sci. Conf., 3, 3165-3179, 1978.

HayAShidA, A. and Y. ITo, Paleoposition of Southwest Japan at $16 \mathrm{Ma}$ : implication from paleomagnetism of the Miocene Ichishi Group, Earth Planet. Sci. Lett., 68, 335-342, 1984.

Hsü, K. J., S. F. Percinal, Jr, R. C. Wright, and N. P. Petersen, Numerical age of magnetostratigraphically calibrated biostratigraphic zones, DSDP Init. Rep., 73, 623-634, 1984. 
InOue, M., Geologic structure of the Chichibu terrain in the Kanto mountainous land, Japan, J. Fac. Sci., Univ. Tokyo, [II], 19, 1-25, 1974.

Koyama, M. and N. Nitssuma, Ring-core-type flux-gate spinner magnetometer and current-regulated three axial alternating field demagnetizer, Geosci. Rep. Shizuoka Univ., 8, 49-61 1983.

Minster, J. B. and T. H. Jordan, Rotation vectors for the Philippine and Rivera Plates, EOS, 60, 958, 1979.

Nitssuma, N., Touchstone of the Plate tectonics-Southern Fossa Magna, central Japan, Chikyu, 4, 326-333, 1982.

Nitsuma, N. and M. Koy AmA, High sensitive automatic astatic magnetometer and three axial alternating field demagnetizer, Geosci. Rep. Shizuoka Univ., 6, 35-43, 1981.

Nitssuma, N. and T. Matsuda, Collision in the South Fossa Magna Area, Central Japan, Rec. Progress, Natural Sci., Japan, 10, 41-50, 1985.

Nirtsuma, N. and F. Axiba, Neogene tectonic evolution and plate subduction in the Japanese Island Arcs, in Formation of Active Ocean Margins, edited by N. Nasu, S. Uyeda, I. Kushiro, K. Kobayashi, and H. Kagami, pp. 75-108, Terrapub, Tokyo, 1985.

Otofuji, Y., A. Hayashida, and M. ToriI, When was the Japan Sea opened?: Paleomagnetic evidence from Southwest Japan, in Formation of Active Ocean Margins, edited by N. Nasu, S. Uyeda, I. Kushiro, K. Kobayashi, and H. Kagami, pp. 551-566, Terrapub, Tokyo, 1985.

SaIto, T., Miocene planktonic Foraminifera from Honshu, Japan, Tohoku Univ., Sci. Rep., 2nd Ser. (Geol.), 35, 123-209, 1963.

Saito, T. and S. MaIYA, Planktonic Foraminifera of the Nishikurosawa Formation, Northeast Honshu, Japan, Trans. Proc. Paleont. Soc. Japan, N,S., 91, 113-125, 1973.

Tamura, J., T. KaneKo, and N. Nitssuma, Geology of the Southern part of the Koma Mountains, western part of Yamanashi Prefecture, Central Japan, Geosci. Rep. Shizuoka Univ., 10, 23-53, 1984. 